\title{
Четыре принципа нормативной архитектуры Китая
}

\author{
М.Ю.Шевченко, НИИТИАГ, Москва
}

Нормативная архитектура Китая, или архитектура «гуаньши», наряду с народной, представляет собой одну из двух важнейших составляющих частей китайского зодчества. Термин «гуаньши» состоит из двух иероглифов: 官 (гуань) - административный, казённый, государственный; и 式 (ши) - образец, норма, стандарт, эталон, тип. Архитектура «гуаньши» - это архитектура, соответствующая определённым государственным нормативам, соблюдению которых уделялось особое внимание со стороны императорского двора. К нормативной архитектуре относились императорские и административные постройки, а также крупные монастыри, храмы, захоронения, резиденции знати, важные фортификационные сооружения и другие. Иными словами, принадлежность к разряду нормативной архитектуры не была связана с функцией построек, а также с их географическим положением на территории Поднебесной.

В данном исследовании нормативная архитектура Китая рассматривается как единое феноменальное явление, основу которого составляли четыре базовых принципа: модульность, иерархичность, пространственная регулярность и единство числовых и геометрических пропорций. В статье кратко раскрыто содержание данных принципов, исследован процесс формирования нормативной архитектуры, который начался на рубеже IV-III тысячелетий до н.э. и завершился к VI веку нашей эры. Вскрыта связь четырёх принципов с различными аспектами традиционного китайского мировоззрения. Выявлен преемственный характер формирования и развития нормативной архитектуры. Кроме того показано, почему архитектура, не обладающая одним или несколькими базовыми принципами, не может быть отнесена к разряду нормативной и как в этом случае меняется её характер.

Ключевые слова: нормативная архитектура Китая, модульность, иерархичность, пространственная регулярность, единство числовых и геометрических пропорций.

\section{Four Principles of Normative Architecture of China}

\section{M.Y.Shevchenko, NIITIAG, Moscow}

China's normative or "guanshi" architecture, along with vernacular architecture, is one of the two most important components of Chinese traditional architecture. The term "guanshi" consists of two characters: 官 guan - administrative, official; and 式 shi - norm, type. "Guanshi" architecture complies with certain government regulations, the observance of which was given special attention by the imperial court.
Belonging to the category of normative architecture was not associated with the function of buildings, as well as with their geographicallocation in the territory of the Celestial Empire.

In this study, China's normative architecture is viewed as a single phenomenon, based on four basic principles: modularity, hierarchy, spatial regularity and unity of numerical and geometric proportions. The article briefly discloses the content of these principles, examines the process of forming a normative architecture, which began at the turn of the 4th-3rd millennia $B C$. and ended by the 6 th century AD. The connection between the four principles and various aspects of the traditional Chinese worldview is identified. The successive nature of development of the normative architecture is revealed. Besides, it is shown why an architecture that does not possess one or several basic principles cannot be classified as normative and how, in this case, its nature changes.

Keywords: China's normative architecture, modularity, hierarchy, spatial regularity, unity of numerical and geometric proportions.

Традиционная архитектура Китая подразделяется на две главные составные части: нормативное и народное зодчество. Понятие «гуаньши», или «нормативная» архитектура, впервые употребил ученый Лян Сычэн в 1934 году в предисловии к своей книге «Строительные правила цинского образца» [1, с. 51]. Термин «гуаньши» состоит из двух иероглифов: 官 (гуань) - административный, казённый, государственный; и 式 (ши) - образец, норма, стандарт, эталон, тип. То есть архитектура «гуаньши» - это архитектура, соответствующая определённым государственным нормативам. К нормативной архитектуре относились постройки императорского двора и администрации, а также крупные монастыри, храмы, захоронения, резиденции знати, важные фортификационные постройки и др. Иными словами принадлежность к разряду нормативной архитектуры не была связана с функцией построек, а также с их географическим положением на территории Поднебесной. Что касается времени возникновения нормативной архитектуры, то, опираясь на данные исследования сохранившихся деревянных сооружений, можно предположить, что оно произошло не позднее VI века.

Нормативная архитектура, обладая единым мировоззренческим базисом и подчиняясь правилам, которые эволюционировали преемственно, может изучаться как целостное феноменальное явление, которое основано на воплощении четырёх 
принципов: модульности, иерархичности, пространственной регулярности и единства числовых и геометрических закономерностей. Каждый из четырёх принципов в свою очередь включает в себя ряд позиций, которые отображены в таблице 1.

Модульность нормативной архитектуры выражается в использовании различных модулей при построении деревянного каркаса, причем модули менялись с течением времени, а также в зависимости от типа сооружения. Величина основного модуля была связана с сечением типового бруса кронштейна доугун: в архитектуре XI-XIII веков использовалась высота данного сечения (цай) ${ }^{1}$, а в архитектуре XVII - начала XX веков - ширина (доукоу) ${ }^{2}$. Кроме того, в сунской архитектуре основной модуль дополнительно делился на 15 частей, что образовывало малый модуль - модульную единицу фэнь (дословно - часть) ${ }^{3}$, который использовался для обозначения размеров небольших конструктивных и декоративных элементов. В случае, если в постройке отсутствовали

1 [宋] 李诫 《营造法式》(Ли Цзе, Инцзао фаши, дин. Сун).

2 [清] 清工部《工程做法则例》 (Министерство работ династии Цин. Строительные методы и правила, дин. Цин).

3 [宋］李诫 《营造法式》(Ли Цзе, Инцзао фаши, дин. Сун).

Таблица 1. Принципы нормативной архитектуры Китая и их составляющие

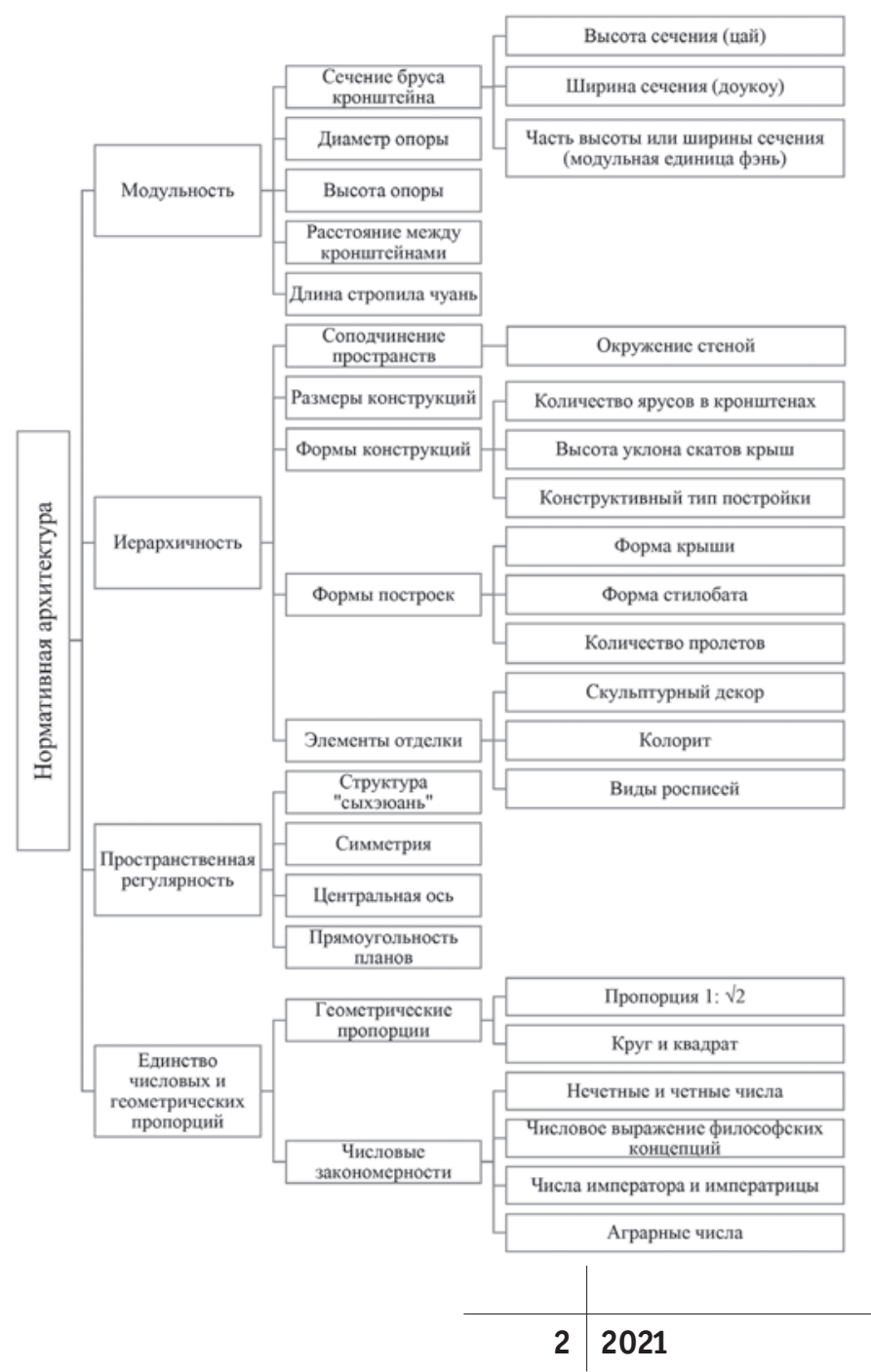

кронштейны доугун, основным модулем становился диаметр карнизных опор [2, с. 12-13]. В многоярусных постройках, таких как терема, башни и пагоды, в качестве модуля нередко использовали высоту карнизных опор [3]. В поздней архитектуре династии Цин, начиная с XVIII века, появляется еще одна зафиксированная величина для расчёта размеров планов построек - расстояние между кронштейнами доугун, обозначенное в трактате «Гунчэн цзофа цзэли» как 11 модулей доукоу [4, с. 31]. Помимо этого, в качестве модуля могла выступать и длина стропильных сочленений чуань, которая фиксировала размер построек по глубине и определяла тип деревянного каркаса: двухстропильный, четырёхстропильный...десятистропильный [5, с. 40].

Иерархичность в нормативной архитектуре проявлялась как на уровне деталей отделки, так и в формах построек в целом. Ранг сооружения мог быть выражен следующими средствами:

- размером основного модуля: в архитектуре династии Сун (960-1279) модуль цай подразделялся на восемь рангов, а в архитектуре Цин (1644-1912) модуль доукоу - на одиннадцать [5];

- количеством ярусов в кронштейнах доугун, максимальное число которых могло достигать восьми ;

- типом деревянного каркаса: с декоративным потолком (тип дяньгэ) и без декоративного потолка (тип тинтан)5. Тип тинтан считался менее статусным, чем дяньгэ;

- углом наклона скатов крыш: чем больше был угол, тем более значительной была постройка [4, с. 28];

- формой крыш: в китайской архитектуре было разработано несколько типов крыш, наиболее значительным из которых была четырёхскатная крыша, а наименее статусным - двускатная [6, с. 15];

- формой стилобатов: стилобаты могли иметь несколько ярусов, их максимальное количество могло достигать трёх. Соответственно трёхъярусные стилобаты имели высший ранг, а одноярусные - низший. Кроме того, значение построек дополнительно могло быть подчёркнуто возведением белокаменных резных ограждений по периметру стилобатов. Такое убранство могли иметь стилобаты только императорских сооружений [4, с. 201];

- размером построек: ширина построек определялась количеством пролётов, которое варьировалось от одного до тринадцати ${ }^{6}$;

- элементами отделки: статус сооружения выражал скульптурный декор на коньках черепичных крыш, типы и сюжеты росписей деревянных элементов конструкций, а также колористическое решение построек [7];

- пространственной организацией: в планировках архитектурных комплексов выделялось центральное сооружение,

4 [宋] 李诫 《营造法式》 (Ли Цзе, Инцзао фаши, дин. Сун).

5 [宋] 李诫 《营造法式》 (Ли Цзе, Инцзао фаши, дин. Сун).

6 [宋] 李诫 《营造法式》 (Ли Цзе, Инцзао фаши, дин. Сун). 
соблюдалось соподчинение объёмов и пространств, территория окружалась стеной, также выражавшей ранг всего комплекса.

Пространственная регулярность начала зарождаться в китайской архитектуре еще в бронзовом веке, на рубеже III и II тысячелетий до нашей эры [8]. Тогда появляются комплексы прямоугольной в плане формы с подчёркнутой осью симметрии, с ориентацией главных ворот в сторону юга, последовательным чередованием дворов. Так начала складываться композиция сыхэюань, главной характеристикой которой был окружённый постройками прямоугольный двор. Дворцовые постройки Эрлитоу (XIX-XVII вв. до н.э.) представляют собой наиболее древние примеры комплексов с такой композицией [9], при династии Чжоу композиция сыхэюань получает дальнейшее развитие [10, с. 34], а после воцарения династии Хань становится пространственным стереотипом устройства архитектурных комплексов в Китае [6, с. 48-49]. Регулярная композиция сыхэюань применялась в комплексах различного функционального назначения и географического положения и была достаточно гибкой, приспосабливаясь к климатическим особенностям различных регионов Китая.

Единство числовых и геометрических пропорций было теснейшим образом связано с китайской нумерологией и дуалистическим мировоззрением, в основе которого лежало представление о двух равноценных противоположностях: силах инь и ян. Считалось, что они порождают всё многообразие вещей в Поднебесной. В числовом выражении этот дуализм проявлял себя как противопоставление чётных (инь) и нечётных (ян) чисел. А в геометрическом выражении - как формы квадрата (инь) и круга (ян) [11, т. 5, с. 28-52]. Геометрическое выражение сил инь и ян могло быть формально буквальным. Это относится к формам алтарей земли (квадрат) и неба (круг), или к структуре храма-дворца Минтан с квадратным нижним ярусом и круглым верхним. Однако было и косвенное выражение взаимодействия двух сил, породившее пропорцию 1: $\sqrt{2}$, так как такое соотношение имеет сторона квадрата к диаметру описанного вокруг него круга. Эта пропорция была описана в сунском трактате по строительству «Инцзао фаши», составленном в 1103 году ${ }^{7}$. Также о важности соотношения размеров кругов и квадратов сказано и в трактате «Канон расчёта чжоуского гномона» ${ }^{8}$, который датируется приблизительно концом III века до н.э. Данная пропорция прослеживается и в структуре деревянного каркаса китайских построек различных династий [12].

Числовое выражение дуализма инь-ян проявилось в том, что со временем числа стали наделяться определённым символическим содержанием, и помимо просто деления на чётные - иньские, и нечётные - янские, числа появились также особые земные и небесные числа, числа императора и императрицы, аграрные числа, числа небесных созвездий

7 [宋] 李诫 《营造法式》(Ли Цзе, Инцзао фаши, дин. Сун).

8 [唐] 张九龄《大唐六典》卷七。(Чжан Цзюлин. Датан Людянь. Том 7. Дин. Тан).
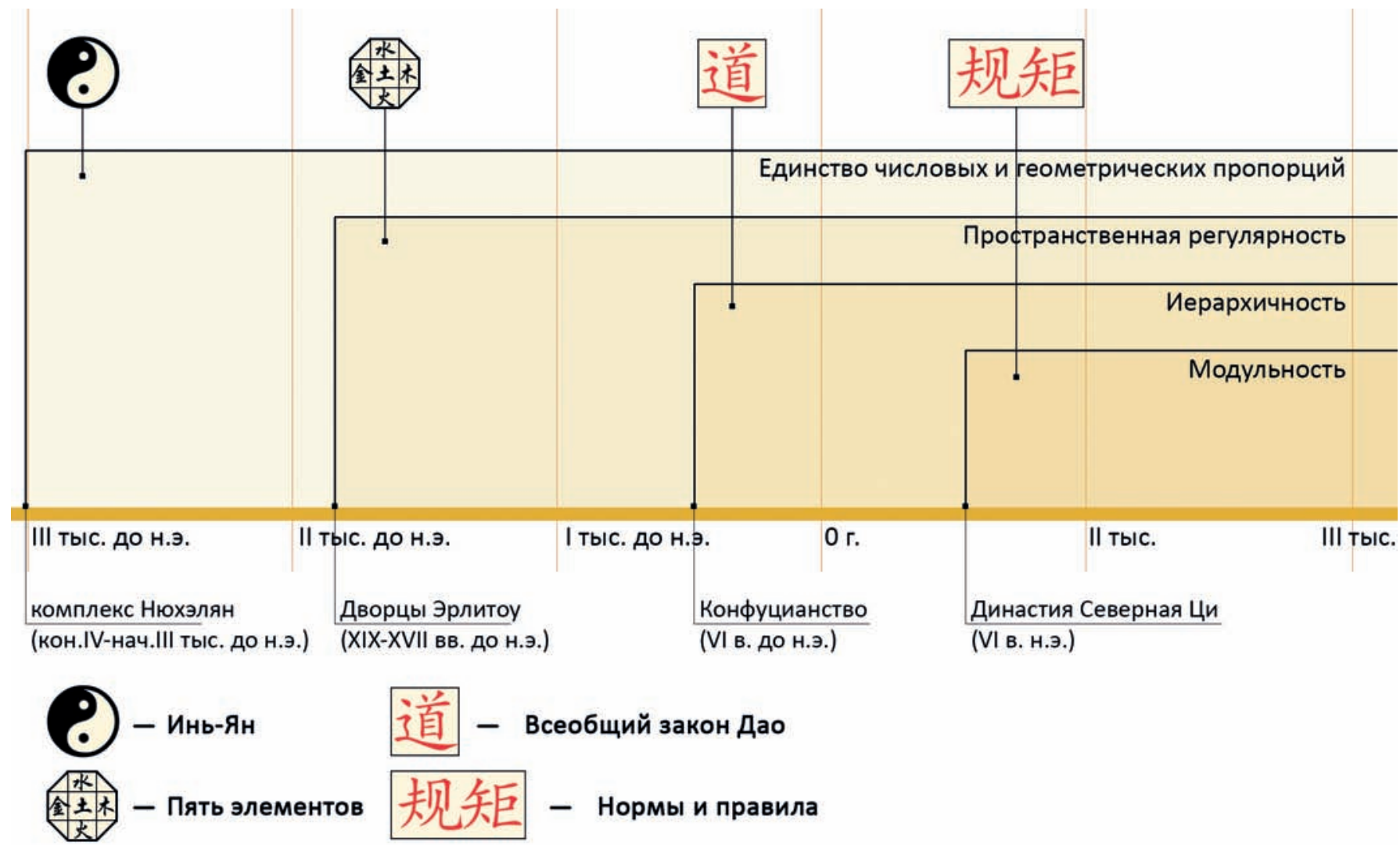

Pис. 1. Схема эволюции нормативной архитектуры Китая. Автор схемы М.А. Шевченко 
и так далее. Соответственно данная символика при необходимости переносилась на структуру сооружений и напрямую выражалась в их пропорциях. Наиболее показательным в этом плане может быть пример с количеством плит мощения алтарей Земли и Неба в Пекине [13]. В алтаре Земли количество плит мощения на каждом ярусе кратно шести - числу земли, а в алтаре Неба - девяти, числу неба.

\section{Развитие четырёх принципов нормативной архитектуры и их связь с мировоззрением}

Как показал анализ формирования признаков нормативной архитектуры Китая, их появление шло постепенно и последовательно, причём каждый новый возникавший принцип не отвергал предыдущего, а как бы накладывался на него, внося некоторые новые черты (рис. 1). Археологические свидетельства говорят о том, что принцип единства числовых и геометрических пропорций проявил себя на территории Китая ранее других. Свидетельством тому служит находка ритуального комплекса в районе Нюхэлян, который датируется концом IV - началом III тысячелетия до нашей эры [14]. Данный комплекс состоит из двух алтарей: двухступенчатого квадратного и трёхступенчатого круглого, причём размеры террас точно соответствуют друг другу, образуя взаимосвязь вписанных и описанных геометрических фигур [15, с. 466]. Этот период не доносит до нас свидетельств существования письменности, наиболее ранние письмена на костях животных датируются не ранее XIII века до н.э. [16, с. 175-182], поэтому мы не можем достоверно утверждать, что в то время уже существовали представления о силах инь и ян, однако столь точное соответствие размеров двух данных алтарей и их схожесть с формами и структурой поздних алтарей Земли и Неба наталкивает на мысль об аналогичных мировоззренческих представлениях. Противоположности инь и ян по сути дела представляют собой одну из форм осмысления окружающего мира, что порождает и модель вселенной с квадратной землёй и круглым (или полусферическим) небом над ней. Не случайно одним из самых ранних зафиксированных письменно правил, регулирующих формы построек, было наличие квадратного нижнего яруса и круглого верхнего яруса у храма минтан [17]. Поэтому находка в Нюхэлян может свидетельствовать о том, что дуалистические представления формируются на территории Китая одними из первых, а потому и в архитектуре своё отражение получают ранее других. Видимо довольно рано появляется и ассоциация силы ян с югом, а инь - с севером, так как уже постройки некоторых неолитических поселений демонстрируют ориентацию главных входов не на центральную площадь поселения, а в сторону юга [18].

Следующий принцип, нашедший своё выражение в китайской архитектуре, - это пространственная регулярность. Наиболее древние свидетельства зарождения регулярной композиции доносят постройки ещё таких неолитических стоянок, как Ванчэнган (王城岗) [8] и Пинлянтай (平粮台)
[19], которые датируются началом II тыс. до н.э., однако в более зрелом виде регулярность демонстрируют дворцовые комплексы культуры Эрлитоу, относящиеся к XIX-XVII векам до н.э. [9]. В построении данных дворцов уже прослеживаются основные структурные составляющие композиции сыхэюань: планировка имеет прямоугольную форму, в ней выделяется центральная ось, связывающая южные ворота с главным строением, весь комплекс окружается стеной, по периметру двора возводятся постройки. В данных комплексах ещё не полностью выражена симметрия, но заложенные здесь композиционные принципы продолжат свое дальнейшее развитие как при протогосударстве Шан (XIII-XI вв. до н.э.) [16], так и позднее при династии Чжоу (XI-III вв. до н.э.). Во всех крупных комплексах данного периода главные ворота и главные фасады построек обращены в сторону юга, то есть приоритет южной, янской стороны здесь соблюдается, как и в более ранний период времени.

Одновременно в этот период происходит формирование представлений о пяти элементах у-син, порождённых противоположностями инь и ян. Истоки учения об у-син восходят к древнейшим (кон. II тыс. до н.э.) представлениям о пятеричном устройстве земной поверхности (у-фан - «пять сторон», у-фэн - «пять ветров-направлений»). Развитую форму учение об у-син обрело в IV-II веках до н.э. В дальнейшем оно стало одной из основ нумерологии и неотъемлемой частью практически всех философских и научных построений [11, т. 1, с. 451-452]. Иными словами наиболее ранние представления о пяти элементах были также связаны с пространственным позиционированием человека (пять сторон, пять ветров) на земле. Каждому из пяти элементов соответствовало своё местоположение: огонь - на юге, металл - на западе, вода на севере, дерево - на востоке и земля - в центре. Желание воплотить принцип пяти элементов в архитектуре привёл к появлению квадратных или прямоугольных планов с акцентированным центром. Объединение с существовавшей уже концепцией инь и ян привело к формированию прямоугольных, ориентированных по странам света планировок с усиленной осью север-юг. Для усиления центральной оси композиция комплексов становилась всё более симметричной. Если в ранних комплексах композиционная ось поддерживалась визуальной связью главных ворот и главной постройки без соблюдения строгой симметрии, то уже при династии Чжоу симметричное построение распространяется повсеместно [10, с. 34].

Вслед за пространственной регулярностью появляется и иерархичность. Возникновение иерархии можно назвать следствием предшествовавших планировочных тенденций: наличие центральной оси требовало её акцентирования, расположение в центре элемента земля из системы у-син также требовало своего выражения. То есть центр композиции начал так или иначе выделяться. Постройки, расположенные в центре, делались крупнее, их стилобаты поднимались выше над уровнем земли, вокруг них стала устраиваться отмостка, это 
было одним из наиболее древних средств выделения статуса сооружений [10, с. 30]. У центральных зданий возводилась крыша более сложной формы: уже самые ранние комплексы в Эрлитоу свидетельствуют о том, что центральные постройки в них имели четырёхскатные крыши [9].

Однако полное осмысление принцип иерархичности получил благодаря возникновению учения Конфуция (годы жизни: ок 551-479 гг. до н.э.). В древнейших конфуцианских трактатах, входящих в классическое Тринадцатикнижие, уже встречаются некоторые правила иерархии. Согласно чжоускому правилу о храмах предков, «У сына Неба должно быть семь храмов, три отцовских, три сыновних и один главный родовой храм, итого семь; у чжухоу должно быть пять храмов, два отцовских, два сыновних и один главный родовой храм, итого пять; у дафу должно быть три храма, один отцовский, один сыновний и один главный родовой храм, итого три; у воинов ши один храм...» [20, с. 26]. В трактате Каогунцзи даётся иерархия размеров улиц, высот ворот и городских стен внутри одного города и между городами разных рангов 9 .

Конфуций выдвигает на передний план категорию Дао, то есть великого истинного пути, мудрого и справедливого порядка. В «Изречениях» Конфуция говорится: «Государство, имеющее Дао, не падёт» ${ }^{10}$. Следовать же Дао возможно, лишь следуя серединным путём, то есть путём гармонии. Гармония (和) и ритуал (礼) для Конфуция - два нераздельных и взаимодополняющих принципа: «Применение ритуала вознаграждается гармонией» ${ }^{11}$. Наличие концепции Дао, стоящего во главе всех вещей и упорядочивающего их по принципу гармонии, воплотилось в архитектуре в виде строгой иерархичности и соподчинённости всех элементов, начиная от планировочных композиций крупных комплексов и заканчивая деталями деревянного каркаса и отделки.

Концепция ритуала в конфуцианстве представляла собой свод определённых предписаний и правил, следуя которым можно было достичь гармонии в государстве. Постепенно поле действия ритуала расширялось и с течением времени под его воздействием оказались не только церемониальная и социальная сферы, но и другие области, включая и архитектуру. Уже в «Изречениях» Конфуция есть указания на существование в то время определённых правил в архитектуре, нарушение которых подвергается серьёзной критике: «Ставить стену-экран позволено государям, но Гуань Чжун также поставил стену-экран» ${ }^{12}$. Или там же говорится о сановнике Цзань Вэньчжуне, у которого была комната «в которой на кронштейнах были вырезаны горы, а на столбиках над матицей нарисованы водяные растения» ${ }^{13}$, что по правилам церемониала можно было делать только в ритуальных сооружениях правителя. В комментарии к «Чуньцю», В «Цзочжуань» мы сталкиваемся с недовольством князем Лин из уезда Цин, который около 606 года до н.э. много заплатил, чтобы украсить стены своего дворца скульптурой [21, с. 209]. Иными словами, уже при династии Чжоу начинает формироваться некий набор правил и норм, который определял планировочную и объемную структуру построек, то есть начинает складываться представление о нормативности сооружений.

Однако в полной мере нормативность выразилась только после установления модульной системы деревянного каркаса. Самая ранняя из дошедших до нас модульных систем была описана в трактате «Инцзао фаши» 1103 года, однако исследование сохранившихся сооружений говорит о том, что система модульных пропорций сложилась гораздо раньше. Так, все сохранившиеся до наших дней деревянные сооружения династии Тан демонстрируют сформировавшуюся систему кронштейнов доугун и соответствие модульных размеров сечений кронштейнов и остальных конструкций [22, с. 364]. К сожалению, более ранних деревянных построек в Китае не сохранилось, и о существовании модульной системы можно судить лишь по косвенным свидетельствам, одним из которых может быть деревянный саркофаг князя Шэди Хуэйло, одного из основателей династии Северная Ци, скончавшегося в 562 году. Декоративное убранство саркофага повторяет конструкции деревянной постройки. Исследовав их размеры, Фу Синянь пришел к выводу, что в них имеется определённая закономерность [23, с. 315-317]. Все части карнизного пояса стандартизированы и соразмерны друг другу и в отдельных элементах прослеживается взаимосвязь размеров, схожая с описанной в трактате «Инцзао фаши». Более ранних свидетельств деревянных построек найдено не было, а по косвенным данным, таким как керамические модели домов или рельефы и росписи, судить о наличии модульности построения каркаса не представляется возможным, так как такие изображения были достаточно сильно упрощены и видоизменены по сравнению с деревянными прототипами. Кроме того, модульность деревянного каркаса в значительной степени связана с конструкцией кронштейнов доугун. Но, как показывают косвенные свидетельства II-VI веков, наиболее сложная угловая конструкция доугун полностью складывается только к VII веку, о чём свидетельствуют росписи пещер Могао в Дуньхуане, датируемые ранним периодом династии Тан [24]. Поэтому можно предположить, что формирование модульного построения деревянного каркаса начинается около VI века и завершается в VII веке. А поскольку мы утверждаем, что без наличия всех вышеуказанных четырёх признаков архитектурные объекты не могут быть отнесены к разряду нормативных, то и нижняя хронологическая граница возникновения нормативной архитектуры должна определяться VI веком.

9 [汉］《周礼・冬宫考工记》. (Чжоули: Каогунцзи, дин. Хань).

10 “邦有道, 不废” - [周] 《论语》 《公治长》( «Изречения», глава «Гунъе Чан», дин.Чжоу).

${ }_{11}$ “礼之用, 和为贵” - [ 周 ] 《论语》 《学而》( 《Изречения», глава «Учиться и...», дин.Чжоу).

12 “邦君树塞门, 管氏亦树塞门” - [周] 《论语》 《八佾》 ( «Изречения», глава «Ба-и», дин.Чжоу).

13 “山節藻梲” - [ 周 ] 《论语》 《公治长》( «Изречения》, глава «Гунъе Чан», дин.Чжоу). 


\section{Преемственный характер развития}

За время своего существования с VI по начало XX века нормативная архитектура в Китае демонстрировала преемственный характер развития. Принцип преемственности возвёл до абсолюта ещё Конфуций, который почитал правителей древности и ратовал за то, чтобы следовать законам праотцов. Сам он говорил: «Передаю, но не создаю; верю в древность и люблю её» ${ }^{14}$. Как показано на схеме (рис. 1), появление новых принципов, составивших в итоге основу нормативной архитектуры Китая, не отменяло действие уже существовавших ранее, но лишь дополняло их. То же происходило и на уровне мировоззрения: появлявшиеся новые мировоззренческие концепции не отвергали уже имевшихся. Сформировавшись к VI веку, нормативная архитектура, развиваясь далее и видоизменяясь, продолжала следовать принципу преемственности. Это наглядно демонстрирует текст трактата по строительству династии Цин - «Гунчэн цзофа цзэли».

В сунском трактате «Инцзао фаши» также подчеркивается преемственность правил древности. Первая же иллюстрация трактата заимствована из чжоуского астрономического трактата «Канон расчёта чжоуского гномона» и представляет собой изображение квадрата, вписанного в круг, и круга, вписанного в квадрат ${ }^{15}$. В этой иллюстрации мы видим отсылку к дуалистической картине мира с силами инь и ян, которая, как мы уже сказали, проявляет себя на самой ранней стадии формирования китайской архитектуры. То, что именно эта иллюстрация была позаимствована автором трактата «Инцзао фаши» и поставлена на первое место, указывает на её основополагающий характер при формировании пропорциональных соотношений нормативного деревянного каркаса. Анализ китайских построек показал, что соотношения круга и квадрата, выразившееся в пропорции 1: $\sqrt{2}$, прослеживается как в размерах сечений элементов деревянного каркаса, так и в конфигурациях фасадов и разрезов построек и планировок целых архитектурных комплексов [12]. Интересно также само слово «норма» в китайском языке, которое звучит как «гуйцзюй» (规矩) и состоит из двух иероглифов: циркуль - гуй (规) и угольник - цзюй (矩). В «Каноне расчёта чжоуского гномона» говорится: «Дела десяти тысяч вещей вершатся при помощи круга и квадрата, работы великих мастеров выполняются при помощи циркуля и угольника» ${ }^{16}$. В том же трактате именно циркуль и угольник выдвигаются как инструменты для измерения вселенной. И здесь мы видим интерпретацию древней пары противоположностей инь и ян на новом витке её осмысления в виде правил «гуй-цзюй», в виде «циркуля и угольника». Преемственность и неизменность базовых принципов обеспечили единство нормативной архитектуры
Китая на протяжении всего периода её существования с VI по начало XX века. Это и позволяет исследовать её как единый феномен.

Далее необходимо остановиться на вопросах того, почему архитектура, не обладающая одним из вышеуказанных принципов, не может называться нормативной и как видоизменяется её характер, если один или несколько принципов не соблюдаются. Ниже мы последовательно рассмотрим все четыре принципа.

1. В народном зодчестве единство числовых и геометрических пропорций не соблюдается практически никогда, что порождает сооружения необычных пропорций и непривычных глазу членений. Здания могут быть чересчур растянутыми в длину, либо же, наоборот, очень узкими. Количество пролётов на главных фасадах может быть чётным, членения построек дробными и так далее ${ }^{17}$. Единство числовых и геометрических пропорций выражает концепцию двух противоположностей инь и ян, которая в нормативной архитектуре была тесно связана с императорским ритуалом, выражение чего не допускалось в простых постройках. В народе силы инь и ян также почитались, но со временем они стали частью популярного среди простых людей учения фэншуй и проявляли себя в архитектуре уже косвенно - через правила фэншуй, а не через императорские установления.

2. Пространственная регулярность, напротив, нарушается в народной архитектуре довольно редко. В китайской архитектуре, как нормативной, так и народной, оказалось очень сильным тяготение к пространственной композиции сыхэюань, поскольку такая композиция была достаточно гибкой и легко приспосабливалась к различным климатическим особенностям. Тем не менее в китайской архитектуре со временем появились отдельные комплексы, не обладавшие регулярностью. Это горные монастыри и парковые ансамбли. И те, и другие к нормативному зодчеству отнести нельзя. Это касается и императорских парков. Императорская парковая архитектура всегда стояла особняком от нормативной, она сближалась скорее с живописью и поэзией [25, с. 259], и даже противопоставлялась нормативной архитектуре с её жёсткими правилами. Эта архитектура следовала естественности природы и отвергала чёткую структурированность и осевое построение ${ }^{18}$. В парковых строениях намеренно шли на нарушение норм, что выражалось в отсутствии коньков на крышах, отсутствии кронштейнов, однотонных росписях, в несоответствии рангу императорских построек и т.д. Это делалось специально, чтобы подчеркнуть отличие парковой архитектуры от нормативной. В то же время, если часть парка занимал путевой дворец императора или же там находилась

\footnotetext{
14 “述而不作, 信而好古” - [周]《论语》《述而》( «Изречения», глава «Передаю...», дин.Чжоу).

15 [宋］李诫 《营造法式》(Ли Цзе, Инцзао фаши, дин. Сун).

16 [唐] 张九龄《大唐六典》卷七。(Чжан Цзюлин. Датан Людянь. Том 7. Дин. Тан).

17 [唐] 张九龄《大唐六典》卷七。(Чжан Цзюлин. Датан Людянь. Том 7. Дин. Тан).

${ }^{18}$ [明] 计成《园冶》 (Цзи Чэн. Устроение садов, дин. Мин).
} 
важная ритуальная постройка, то на строго отведённой территории дворца или храма внутри парка все принципы нормативной архитектуры, включая и пространственную регулярность, могли быть соблюдены [26].

3. Иерархичность нарушалась ещё при жизни Конфуция, и это продолжалось на всем протяжении существования китайской традиционной архитектуры. Чаще всего ранг зданий в народной архитектуре повышался в нарушение существовавших норм за счёт использования кронштейнов доугун и элементов декора. В результате в народном зодчестве появился такой феномен как чрезмерный декор. Это особенно характерно для южных регионов Китая, таких как провинции Фуцзянь или Гуандун, но отчасти проявило себя и в северных провинциях, к примеру в провинции Шаньси. Но, как было отмечено выше, существуют примеры намеренного понижения статуса сооружения, что характерно для парковой архитектуры как императорской, так и частной. К примеру, частные сады Сучжоу или Янчжоу демонстрируют нарочитую простоту конструкций и полное отсутствие следованию нормативам построения деревянного каркаса [27].

4. Модульность каркаса - наиболее сложный принцип нормативной архитектуры, сформировавшийся позднее других. Не случайно именно его описанию главным образом и посвящены трактаты по строительству «Инцзао фаши» и «Гунчэн цзофа цзэли». Освоение этого принципа требовало отдельной подготовки и мастерства, поэтому оно неразрывно связано с императорским домом и императорской администрацией. Именно соблюдение модульного построения подвергалось наибольшему контролю со стороны администрации. Поэтому по своей сути этот принцип несовместим с народной архитектурой и практически отсутствует в ней. Однако были периоды времени, когда модульность нарушалась и в императорской архитектуре. Эти периоды неразрывно связаны с ослаблением контроля со стороны императорского дома. Это произошло, к примеру при воцарении монгольской династии Юань (1271-1368), чьи правители, будучи этнически не китайцами, не уделяли большого внимания соблюдению прежних строительных норм, что привело к повсеместному отходу от них, а также к возникновению новых конструктивных и типологических решений [28]. Следствием этого стало также забвение специфической строительной терминологии, поэтому пришедшая на смену монголам в 1368 году династия Мин, объявившая о возрождении пребывавшей в упадке китайской культуры, вынуждена была воссоздавать утерянную терминологию, что привело к возникновению совершенно иного терминологического аппарата, который в последствии и был зафиксирован в трактате «Гунчэн цзофа цзэли» [1, с. 9-14].

Исследование нормативной архитектуры Китая как единого феномена позволило выявить её основные принципы и вскрыть общие закономерности её развития. Четыре принципа: модульность, иерархичность, пространственная регулярность и единство числовых и геометрических пропорций, формировались постепенно, а их возникновение было тесно связано с процессом эволюции китайского традиционного мировоззрения. K VI веку процесс формирования нормативной архитектуры в целом был завершён, после чего началось её последовательное развитие вплоть до начала XX века. Развитие нормативной архитектуры имело ярко выраженный преемственный характер, что обуславливалось опорой на конфуцианское учение. Это привело к отсутствию резких изменений в планировочных, объёмно-пространственных и конструктивных построениях. В этом лежит объяснение стилевой устойчивости китайской нормативной архитектуры на всём протяжении её существования c VI по начало XX века.

\section{Лumepamypa}

1. Sun Zhuqing. Royal Buildings with Civil Construction: The Exploration of Civil Construction Techniques in the Taoist Classics Library in Wudang Complex / Sun Zhuqing // South Architecture, 2014. - №1. - C. 50-56.

2. 马炳坚。中国古建筑木作营造技术。(Ма Бинцзянь. Техника возведения деревянного каркаса в древнекитайской архитектуре). - Пекин : Кэсюэ, 2003. - 353 с.

3. Фу Синянь. Особенности архитектуры Китая эпохи Южных и Северных династий, династии Суй и династии Тан, отражённые в архитектуре Японии периодов Асука и Нара// Архитектура Китая: два взгляда / Ред. Г.В. Есаулов и др. - М., СПб : Нестор-История, 2013. - С. 36-67.

4. 梁思成。中国建筑史。(Лян Сычэн. История архитектуры Китая). - Тяньцзинь: Байхуа Вэньи, 1998. - 329 с.

5. 潘谷西、何建中。营造法式解读。(Пань Гуси, Хэ Цзяньчжун. Исследование трактата «Инцзао фаши»). - Нанкин : Издательство Юго-восточного университета, 2005. - 321 с.

6. 刘敦桢。中国古代建筑史。(ЛюДуньчжэнь. История древнекитайской архитектуры, второе издание). - Пекин : Чжунго цзяньчжу гунъе, 2003. - 423 с.

7. 李路珂。营造法式彩画研究。(Ли Лукэ. Исследование росписей из трактата «Инцзао фаши»). - Нанкин : Издательство Юго-восточного университета, 2011. - 408 с.

8. 安金槐、李京华。登封王城岗遗址的发掘。(Ань Цзиньхуай, Ли Цзинхуа. Исследование стоянки Ванчэнган города Дэнфэн) // 《文物》Вэньу. - 1983. - № 3. - С. 8-20.

9. 许宏、陈国梁、赵海涛。二里头遗址聚落形态的 初步考察。(Сюй Хун, Чэнь Голян, Чжао Хайтао. Начальное исследование характера поселения в Эрлитоу) // 《考古》 Каогу. - 2004. - № 11. - С. 23-31.

10. 陕西周原考古队。陕西岐山凤雏村西周建筑群基址 发掘简报。(Археологическая команда провинции Шэньси по исследованию истоков династии Чжоу. Краткий археологический отчёт о раскопках фундаментов архитектурной группы периода Западное Чжоу в районе Фэнчу, уезда Цишань, провинции Шэньси) // 《文物》Вэньу. - 1979. - № 10. - С. 27-36.

11. Духовная культура Китая : энциклопедия : в 5 томах / ред. М.Л. Титаренко и др. - М. : Восточная литература, 2009. - C. 28-52. 
12. 王南。规矩方圆 天地之和。(Ван Нань. Закон круга и квадрата - гармония неба и земли : в 2 томах) Пекин : Чжунго цзяньчжу гунъе, 2019.

13. 东华图志：北京东城史迹录// 陈平、王世仁。天 津：天津古籍出版社。(Перечень исторических памятников восточной части Пекина// ред. Чэнь Пин, Ван Шижэнь). Тяньцзинь : Тяньцзинь-гуцзи, 2005.

14. 辽宁省文物考古研究所。辽宁牛河梁红山文化”女 神庙”与积石冢群发掘简报。(Научно-исследовательский отдел археологии провинции Ляонин. Краткий отчёт о раскопках «Храма богини» и группы могильных курганов на стоянке Нюхэлян культуры Хуншань в провинции Ляонин) // 《文物》Вэньу. -1986. - № 8. - C. 1-10.

15. 冯时。中国天文考古学。(Фэн Ши. Археоастрономия Китая). - Пекин : Шэхуэй Кэсюэ, 2010. - 558 с.

16. Васильев Л.С. Древний Китай. - в 3 Т. - Т. 1. Предыстория, Шан-Инь, Западное Чжоу (до VIII в. до н.э.). // - М. : «Восточная литература». 1995. - 380 с.

17. 杨鸿勋。宫殿考古通论。(Ян Хунсюнь. Общий обзор археологии дворцовых сооружений). - Пекин : Издательство Цзыцзинчэн, 2000. - 583 с.

18. 中国科学院考古研究所。西安半坡。(Отдел археологии при Академии наук КНР. Поселение Баньпо в (иане). - Пекин : Вэньу, 1963. 320 с.

19. 曹桂岑、马全。河南淮阳平粮台龙山文化城址试 掘简报。(Цао Гуйцэнь, Ма Цюань. Отчёт об исследовании стоянки Пинлянтай культуры Луншань в районе Хуайян провинции Хэнань) // 《文物》 Вэньу. - 1983. - № 3. - С. 8-20.

20. 赵立瀛。陕西古建筑。(Чжао Лиин.Древняя архитектура провинции Шэньси). - Сиань : Шэньси жэньминь, 1992. - 319 с.

21. Sickman Laurence. The art and architecture of China / Sickman Laurence, Soper Alexander // Harmondsworth, 1971.

22. 傅喜年。中国古代城市规划、建筑群布局及建 筑设计方法研究。(Фу Синянь. Исследование принципов планировки древнекитайских городов, архитектурных групп и отдельных построек : в 2 томах. Т. 2. - Пекин : Чжунго цзяньчжу гунъе, 2016. - 523 с.

23. 傅喜年。中国古代建筑史。(Фу Синянь. История древней архитектуры Китая : в 5 томах. Т. 2). - Пекин : Чжунго цзяньчжу гунъе, 2009. - 723 с.

24. 孙儒僩，孙毅华。敦煌石窟全集。建筑画卷。(Сунь Жусянь, Сунь Ихуа. Полный обзор пещер Дуньхуана. Т. 21, Архитектура в росписях). - Гонконг : Шанъу Иньшугуань 2001. -280 c.

25. 刘彤彤。中国古典园林的儒学基因。(ЛюТунтун. Конфуцианские истоки китайского классического парка). Тяньцзинь: Издательство Тяньцзинского университета, 2015. - 316 с.

26. 郭黛姮。远逝的辉煌: 圆明园建筑园林研究与保护。 (Го Дайхэн. Ушедшее великолепие: исследование и охрана архитектуры и ландшафтов парка Юаньминъюань). - Шанхай : Кэсюэ Цзишу, 2009. - 342 с.

27. 刘敦桢。苏州古典园林。(Лю Дуньчжэнь. Классическиепарки Сучжоу).-Пекин:Чжунгоцзяньчжугунъе, 2014.-473с.
28. Шевченко М.Ю. Особенности деревянных сооружений Китая династии Юань (XIII-XIV вв.) // Научно - аналитический журнал «Дом Бурганова. Пространство культуры». - 2018. - № 4. - С. 179-202.

\section{References}

1. Sun Zhuqing. Royal Buildings with Civil Construction: The Exploration of Civil Construction Techniques in the Taoist Classics Library in Wudang Complex. In: South Architecture, 2014, no. 1, pp. 50-56

2. Ma Bingjian. Zhongguo Gujianzhu Muzuo Yingzao Jishu [Wooden construction technology of Chinese ancient architecture]. Beijing, Kexue Publ., 2003, 353 p. (In Chinese)

3. Fu Xinian. Osobennosti arhitektury Kitaja jepohi Juzhnyh i Severnyh dinastij, dinastii Suj i dinastii Tan, otrazhennye $v$ arhitekture Japonii periodov Asuka i Nara [Features of Chinese architecture of Southern and Northern dynasties and the Sui and Tang dynasties, reflected in the architecture of Japan during the Asuka and Nara periods]. In: Arhitektura Kitaja: dva vzgljada [Chinese architecture: two views]. Moscow-Saint Petersburg, Nestor-Istoriya Publ., 2013, pp. 36-67. (In Russ.)

4. Liang Sicheng. Zhongguo Jianzhushi [History of Chinese architecture]. Tianjin, Baihua Wenyi Publ., 1998, 329 p. (In Chinese)

5. Pan Guxi, He Jianzhong. Yingzao Fashi Jiedu [Interpretation of the Yingzao Fashi]. Nanjing, Dongnan Daxue Publ., 2005, 321 p. (In Chinese)

6. Liu Dunzhen. Zhongguo Gudai Jianzhushi [History of Ancient Chinese Architecture]. Beijing, Zhongguo Jianzhu Gongye Publ., 2003, 423 p. (In Chinese)

7. Li Luke. Yingzao Fashi Caihua Yanjiu [Research on wood paintings of the Yingzao Fashi]. Nanjing, Dongnan Daxue Publ., 2011, 408 p. (In Chinese)

8. An Jinhuai, Li Jinghua. Dengfeng Wangchenggang Yizhi de Fajue [Excavation of Dengfeng Wangchenggang Site]. In: Wenwu [Cultural relics], 1983, no. 3, pp. 8-20. (In Chinese)

9. Xu Hong, Chen Guoliang, Zhao Haitao. Erlitou Yizhi Juluo Xingtai de Chubu Kaocha [Preliminary Investigation on the Settlement Form of Erlitou Site]. In: Kaogu [Archeology], 2004, no. 11, pp. 23-31. (In Chinese)

10. Shaanxi Zhouyuan Kaogudui [Shaanxi Zhouyuan Archaeological Team]. Shaanxi Qishan Fengchucun Xizhou Jianzhuqun Jizhi Fajue Jianbao [Brief Report on Excavation of the Foundation Site of the Western Zhou Building Group in Fengchu Village, Qishan, Shaanxi]. In: Wenwu [Cultural relics], 1979, no. 10, pp. 27-36. (In Chinese)

11. Duhovnaja kul'tura Kitaja: jenciklopedija [Spiritual culture of China: an encyclopedia in five volumes]. Moscow, Vostochnaja literatura Publ., 2009. (In Russ.)

12. Wang Nan. Guiju Fangyuan - Tiandi zhi He [The Law Of The Circle And The Square - The Harmony Of Heaven And Earth]. Beijing, Zhongguo Jianzhu Gongye Publ., 2019, 492 p. (In Chinese) 
13. Donghua Tuzhi: Beijing Dongchengshi Jilu [Historical Relics of the East City of Beijing]. Tianjin, Tianjin Guji Publ., 2005, 1568 p. (In Chinese)

14. Liaoningsheng Wenwe Kaogu Yanjiusuo [Liaoning Provincial Institute of Cultural Relics and Archaeology]. Liaoning Niuheliang Hongshan Wenhua "Nvshenmiao" yu Jishizhong Qun Fajue Jianbao [A Brief Report on the Excavation of the "Goddess Temple" and the Stone Tomb Group of the Hongshan Culture in Niuheliang, Liaoning]. In: Wenwu [Cultural relics], 1986, no. 8, pp. 1-10. (In Chinese)

15. Feng Shi.Zhongguo Tianwen Kaoguxue [Archaeoastronomy of China]. Beijing, Shehui Kexue Publ., 2010, 558 p. (In Chinese)

16. Vasil'ev L.S. Drevnij Kitaj [Ancient China], vol. 1. Moscow, Vostochnajaliteratura Publ., 1995, 380 p. (In Russ.)

17. Yang Hongxun. Gongdian Kaogu Tonglun [General Introduction to Palace Archaeology]. Beijing, Zijingcheng Publ., 2000, 583 p. (In Chinese)

18. Zhongguo Kexueyuan Kaogu Yanjiusuo [Institute of Archaeology, Chinese Academy of Sciences]. Xian Banpo [Banpo settlement in Xi'an]. Beijing, Wenwu Publ., 1963, 320 p. (In Chinese)

19. Cao Guicen, Ma Quan. Henan Huaiyang Pingliangtai Longshan Wenhua Chengzhi Shijue Jianbao [A Brief Report on the Excavation of the Site of Longshan Cultural City in Pingliangtai, Huaiyang, Henan]. In: Wenwu [Cultural relics], 1983, no. 3, pp. 8-20. (In Chinese)

20. Zhao Liying. Shanxi Gujianzhu [Shaanxi Ancient Architecture]. Xi'an, Shanxi Renmin Publ., 1992, 319 p. (In Chinese)
21. Sickman Laurence, Soper Alexander. The art and architecture of China. Harmondsworth, 1971.

22. Fu Xinian. Zhongguo Gudai Chengshi Guihua, Jianzhuqun Buju ji Jianzhu Sheji Fangfa Yanjiu [Research on Ancient Chinese Town Planning, Compositions of Building Groups and Architectural Design Methods], Vol. 2. Beijing, Zhongguo Jianzhu Gongye, 2016, 532 p. (In Chinese)

23. Fu Xinian. Zhongguo Gudai Jianzhushi [History of Ancient Chinese Architecture], Vol. 2. Beijing, Zhongguo Jianzhu Gongye Publ., 2009, 723 p. (In Chinese)

24. Sun Ruxiang, Sun Yihua. Dunhuang Shuku Quanji [The Complete Works of Dunhuang Grottoes. Architectural depictions]. Hongkong, Shangwu Yinshuguan Publ., 2001, 280 p. (In Chinese)

25. Liu Tongtong. Zhongguo Gudian Yuanlin de Ruxue Jiyin [Confucian Origins of Chinese Classical Garden]. Tianjin, Tianjin Daxue Publ., 2015, 316 p. (In Chinese)

26. Guo Daiheng. Yuanjin de Huihuang: Yuanmingyuan Jianzhu Yuanlin Yanjiu yu Baohu [Glorious past: Research and Protection of the Architecture and Gardens of Yuanmingyuan]. Shanghai, Kexue Jishu Publ., 2009, 342 p. (In Chinese)

27. Liu Dunzhen. Suzhou Gudian Yuanlin [Classical Gardens of Suzhou]. Beijing, Zhongguo Jianzhu Gongye, 2014, 473 p. (In Chinese)

28. Shevchenko M. Osobennosti derevjannyh sooruzhenij Kitaja dinastii Yuan (XIII-XIVvv.) [Features of wooden structures in China of the Yuan dynasty (XIII-XIV centuries)]. In: Dom Burganova. Prostranstvo kul'tury [House of Burganov. Space of culture], 2018, no. 4, pp. 179-202.

Шевченко Марианна Юрьевна (Москва). Кандидат архитектуры. Профессор кафедры «История архитектуры и градостроительства» ФГБОУ В0 «Московский архитектурный институт (государственная академия) (107031, Москва, Рождественка, 11/4. МАРХИ). Эл.почта: china-arch@yandex.ru.

Shevchenko Marianna Y. (Moscow). Candidate of Architecture, Professor at the Department of History of Architecture and Urban Planning at the Moscow Institute of Architecture (11/4 Rozhdestvenka st., Moscow, 107031. MARKHI). E-mail: china-arch@ yandex.ru. 